\title{
Jeszcze o kwestii żydowskiej w Lalce Bolesława Prusa
}

\author{
On the Jewish question in Bolesław Prus's novel \\ The Doll
}

\author{
|Tomasz Sobieraj
Uniwersytet im. Adama Mickiewicza w Poznaniu
ORCID: 0000-0002-4563-5574
}

\begin{abstract}
Lalka, the most famous novel by Bolesław Prus, published in 1890, was concerned with many aspects of the Jewish question. The author portrayed a few phases in relations between Poles and Jews. The first phase was the short epoch of equality and fraternity before the January Uprising. Then came the period of the assimilation of Jews. Finally, Prus observed a growing process of hostility towards Jews. On the whole, anti-Semitic views were criticized by him both in Lalka, and in his journalism. Yet, on the other hand, it must be acknowledged that Prus was often inclined to perceive Jews in stereotypical ways. Lalka presents an economic triumph of Jews over impractical and inept Poles. Anti-Semitic public feelings that were shown in the novel anticipated the Warsaw pogrom of Jews that took place at the end of 1881.
\end{abstract}

Key words: assimilation, equality, anti-Semitism, hostility, anticipation of a pogrom

Streszczenie: W swojej najwybitniejszej powieści, Lalce, Bolesław Prus poruszył wiele aspektów tzw. kwestii żydowskiej. Pisarz ukazał kilka faz w rozwoju stosunków polsko-żydowskich. Pierwsza to faza braterskiej równości sprzed powstania styczniowego. Następnie zdarzył się okres asymilacji Żydów. Na końcu Prus przedstawił narastającą wrogość wobec Żydów. Ogólnie rzecz ujmując, pisarz krytykował antysemityzm zarówno w Lalce, jak i w swojej twórczości publicystycznej. Z drugiej jednak strony przyznać trzeba, że Prus często postrzegał Żydów w sposób stereotypowy. Lalka ukazuje ekonomiczny triumf Zydów nad niepraktycznymi i nieudolnymi Polakami. Ukazane w powieści nastroje antysemickie zwiastowały warszawski pogrom Żydów z końca 1881 roku.

Słowa kluczowe: asymilacja, równość, antysemityzm, wrogość, zapowiedź pogromu

Lalka Prusa, powieść o zasięgu panoramicznym, okazała się znakomitą syntezą polskiego życia zbiorowego XIX stulecia, w szczególności zaś drugiej jego połowy. O poznawczej wartości tego arcydzieła zaświadczał również sposób przedstawienia przez Prusa tzw. kwestii żydowskiej. Rozumiano przez nią problem wzajemnych relacji Polaków i Żydów oraz miejsca i roli tych drugich w strukturze polskiego społeczeństwa. Była ta 
kwestia zagadnieniem drażliwym, wzbudzała ogromne emocje społeczne, nawarstwiały się w niej konsekwencje wielowiekowej egzystencji Żydów na ziemiach polskich, stosunek do niej - bywało - odzwierciedlał zarówno najszlachetniejsze, jak i najbardziej mroczne strony polskiej mentalności, pełen był też stereotypów kulturowych.

Podejście Prusa do kwestii żydowskiej - ukazane i w Lalce, i w twórczości publicystycznej - sytuuje się w całokształcie jego poglądów społeczno-kulturalnych, stanowi przy tym wyraz określonej świadomości poznawczej, zdeterminowanej przez systemy pojęciowe oraz normy aksjologiczno-etyczne polskiego pozytywizmu, nacechowanej też indywidualnymi zapatrywaniami pisarza ${ }^{1}$. We współczesnej interpretacji tej skomplikowanej problematyki nakładają się na siebie dwie płaszczyzny poznawcze: historycznokulturowa, skoncentrowana na rekonstrukcji macierzystego kontekstu dyskusji wokół kwestii żydowskiej w Polsce w drugiej połowie XIX wieku, oraz, by tak rzec, dzisiejsza, naznaczona świadomością Zagłady, nadająca refleksji historycznokulturowej dodatkowy aspekt etyczny. W stanowisku Prusa wobec kwestii żydowskiej przejawiały się zarówno stereotypy kulturowe, niewolne niekiedy od treści antysemickich, jak i przeświadczenia moralne o wydźwięku ponadczasowym, tworzące piękną kartę polskiego dziedzictwa kulturowego. Tę złożoność problemu trzeba ukazywać w próbach dzisiejszej lektury powieści Prusa. Pozwoli to uniknąć uproszczeń zniekształcających stanowisko pisarza wobec kwestii żydowskiej.

Pozytywiści traktowali tę kwestię jako jeden z najistotniejszych problemów życia zbiorowego, ujmowali ją z polocentrycznego punktu widzenia. Nie byli wobec niej jednomyślni; różnili się między sobą, najczęściej opowiadali się za asymilacją Żydów, czyli procesem włączenia ich w obręb polskiego społeczeństwa w taki sposób, by w jego wyniku powstała organiczna wspólnota narodowa. Miał się ten proces dokonać dzięki przyjęciu przez Żydów polskich wzorców kulturowych, ale przy zachowaniu religii (Cała 1989, 216-267). W dość powszechnym mniemaniu za filosemitkę uchodziła Eliza Orzeszkowa. Świętochowski z wolna ewoluował od stanowisko proasymilacyjnego ku antysemityzmowi. Z kolei Prus - jak można w największym skrócie skonstatować - przyjmował postawę niejednoznaczną. Początkowo zdecydowanie popierał tendencje asymilatorskie, wierzył w możliwość współistnienia Polaków i Żydów, potem - od lat 80. - środowisko żydowskie nierzadko krytykował, rozczarowany niepowodzeniem asymilacji i rzekomym separatyzmem żydowskim. Najczęściej jednak występował przeciwko nietolerancji, ksenofobii, nacjonalizmowi, fanatyzmowi religijnemu, odrzucał antysemityzm nasilający się w Królestwie Polskim choćby na przełomie lat 70 i 80. XIX wieku, a więc w czasie akcji Lalki.

Lalka diagnozuje skomplikowane relacje polsko-żydowskie tamtego okresu. Jest tedy swego rodzaju świadectwem historycznym, zapośredni-

${ }^{1}$ Istnieje cenne monograficzne opracowanie problemu - monografia Agnieszki Friedrich Bolesław Prus wobec kwestii żydowskiej (Friedrich 2008). 
czonym, rzecz jasna, przez literackie konwencje i światopoglądowe stanowisko autora. Przed niespełna pięcioma laty - w 2016 roku - ukazało się w izraelskim Wydawnictwie Carmel wydanie Lalki w przekładzie na język hebrajski, dokonanym przez Miriam Borenstein. Wstępem opatrzył tę edycję Samuel Sandler, zmarły w ubiegłym roku znakomity polski literaturoznawca, autor wielu publikacji poświęconych, między innymi, Świętochowskiemu, Sienkiewiczowi, Strugowi, wydawca pism krytycznych Ignacego Matuszewskiego. Profesor Sandler przeżył wojnę w łódzkim getcie, studia polonistyczne i socjologiczne odbywał na Uniwersytecie Wrocławskim, potem związał się z Instytutem Badań Literackich PAN, był też zatrudniony na Uniwersytecie Łódzkim. W 1969 roku wyemigrował z Polski. Pracował na uniwersytetach w Tel-Awiwie i Chicago.

Znaczna część wstępu Sandlera do Lalki została poświęcona „sprawom żydowskim” powieści, a więc kwestii szczególnie istotnej dla czytelnika, do którego wydanie adresowano ${ }^{2}$. W części tej ujawniają się dwie, ściśle ze sobą połączone, wspomniane na wstępie perspektywy poznawcze, a więc historycznokulturowa i współczesna. Choć w Sandlera lekturze Lalki pulsuje nieuniknione napięcie między tymi perspektywami, to jednak badacz z wielką skrupulatnością skupia się przede wszystkim na odkryciu macierzystego otocza powieści Prusa.

Temat żydowski Lalki parokrotnie poruszono w dziejach jej historycznoliterackiej recepcji, najczęściej jednak - w sposób wycinkowy. Dopiero studium Bogdana Burdzieja przyniosło próbę kompleksowego ujęcia tematu (Burdziej 1998). Badacz ten zinterpretował wątki żydowskie powieści w ich potencjalnym związku z warszawskim pogromem Żydów z grudnia 1881 roku; z nadzwyczajną przy tym skrupulatnością zrekonstruował historyczny kontekst problemu.

Nie ulegało dawniej i dziś nie ulega wątpliwości, że Prus wykreował w swej arcypowieści obraz polskiego społeczeństwie w kryzysowym stanie głębokiego rozkładu. Stosunki polsko-żydowskie są również wyrazem tego stanu ${ }^{3}$. Podejrzliwość, nieufność, separatyzm, wzmagająca się niechęć czy wręcz nienawiść zdają się charakteryzować relacje między Polakami a Żydami w Lalce. Prus odtworzył całą tę atmosferę w sposób wielogłosowy; uwzględnił różne punkty widzenia swoich bohaterów. W charakterystyczny dla siebie sposób starał się oświetlić kwestię żydowską wieloaspektowo, skupiając się przede wszystkim na płaszczyźnie ekonomicznej i społeczno-politycznej. Spostrzeżenia Prusa były, przynajmniej po części, adekwatne

${ }^{2}$ Polskiego przekładu doczekała się też pozostała część wstępu Sandlera do hebrajskiego wydania Lalki. Jest to bardzo kompetentna - odwołująca się do najnowszych ustaleń badawczych - charakterystyka problematyki i poetyki powieści Prusa, która w odczuciu Sandlera jest dziełem wzbudzającym coraz większe zainteresowanie czytelników i literaturoznawców. Autor wstępu podkreślił, że zamiarem jego było „przedstawić (...) ważne (...) problemy i cechy nowatorstwa tematycznego Lalki i kunsztu pisarskiego Prusa konstytutywne dla kształtu jego wielkiej powieści” (Sandler 2017, 192).

${ }^{3}$ Józef Bachórz wnikliwie napisał: „Kryzys (...) «kwestii żydowskiej» w powieści Prusa jest jednym z ważnych składników pesymistycznego obrazu społeczeństwa w «rozkładzie», który to «rozkład» zdaniem Prusa w znacznej mierze pochodzi z trwania anachronicznego dziedzictwa, w tym i dziedzictwa antysemickiego" (Bachórz 1998, CXV). 
w stosunku do położenia Żydów w Europie Środkowo-Wschodniej. Sandler napisał, że „«kwestia żydowska» - po wcześniejszym rozwiązaniu sprawy pańszczyźnianej - stała się (...) najbardziej widocznym wewnętrznym konfliktem społeczno-politycznym w społeczeństwie polskim ostatnich dziesięcioleci XIX wieku" (Sandler 2016, 169).

Żydowscy bohaterowie Lalki to postacie zróżnicowane i zindywidualizowane, nakreślone z prawdziwym mistrzostwem od strony psychologicznej. Wybijają się na plan pierwszy Szlangbaumowie, ojciec i syn Henryk, zaprzyjaźnieni z Wokulskim, reprezentujący sferę średniozamożną, oraz lekarz Michał Szuman, jeden z najwyrazistszych bohaterów powieści, weredyk, intelektualista przenikliwie, acz niekiedy z radykalną przesadą, diagnozujący stan kultury współczesnej i wzajemne relacje Żydów i Polaków.

Stary Szlangbaum to Żyd ortodoksyjny, życzliwie jednak odnoszący się do Polaków i polskości, troskliwy w stosunku do rodziny, niechętny wobec asymilacyjnych skłonności syna ${ }^{4}$, doceniający życzliwość i wsparcie Wokulskiego. Znakomicie spełnia się w roli finansisty, prawdopodobnie para się lichwą, ma wielki talent do interesów (co sam Prus uznawał za naturalną cechę Żydów), poważa i lubi Wokulskiego, pomaga mu w zakupie kamienicy Łęckich. Szlangbaum parokrotnie występuje w toku akcji powieściowej, stając się protagonistą świetnych scen fizjologicznych (wyróżnia się wśród nich jego opowieść o wnuku i rodzinie). Bohater ten wykłada Wokulskiemu swój pogląd na temat charakteru i mentalności Żydów, którzy nawet wolny czas poświęcają na rozrywki umysłowe, rozwijając umysł. Sens wypowiedzi Szlangbauma wydaje się bliski zapatrywaniom samego Prusa; bohater powiada:

U nas, panie, niby u Żydów, jak się młodzi zejdą, to oni nie zajmują się, jak u państwa, tańcami, komplementami, ubiorami, głupstwami, ale oni albo robią rachunki, albo oglądają uczone książki, jeden przed drugim zdaje egzamin albo rozwiązują sobie szarady, rebusy, szachowe zadanie. U nas ciągle jest zajęty rozum i dlatego Żydzi mają rozum, i dlatego, niech się pan nie obrazi, oni cały świat zawojują. U państwa wszystko się robi przez te sercowe gorączkę i przez wojnę, a u nas tylko przez mądrość i cierpliwość (Prus 1998, I 391).

Te umysłowe predyspozycje zapewniały Żydom przewagę w stosunkach ekonomicznych; były one zarazem przyczyną nasilającej się niechęci do nich, prezentowanej przez Polaków. I Rzecki, i inni bohaterowie powieści dostrzegali tę coraz gęstszą atmosferę negatywnych emocji w stosunku do żydowskiej ludności Warszawy, stanowiącej wtedy jedną trzecią mieszkańców miasta. Stary subiekt notował w swoim pamiętniku:

W ogóle, może od roku, uważam, że do starozakonnych rośnie niechęć; nawet ci, którzy przed kilkoma laty nazywali ich Polakami mojżeszowego wyznania, dziś zwą ich Żydami. Zaś ci, którzy niedawno podziwiali ich pracę, wytrwałość i zdolności, dziś widzą tylko wyzysk i szachrajstwo (Prus 1998, I 304).

${ }^{4} \mathrm{~W}$ chwil emocjonalnego uniesienia stary Szlangbaum „po raz setny z rzędu wyklął swego syna za to, że nazywa się Henrykiem, chodzi w surducie i jada trefne potrawy" (Prus 1998, I 526). 
Zapiski Rzeckiego - dotyczące zdolności umysłowych Żydów oraz ich tradycyjnych zajęć - można by potraktować jako wyraz stereotypowego myślenia Prusa, który zarówno ich pozytywne, jak negatywne cechy opisywał w sposób silnie utrwalony w ówczesnej świadomości zbiorowej. Pisała szczegółowo o tej kwestii Friedrich (Friedrich 2008, 194-201). I Lalka nie jest wolna od stereotypowego postrzegania Żydów. Z punktu widzenia tragicznych doświadczeń diaspory żydowskiej w wieku XX razić muszą niektóre opinie Prusa, odnoszące się do charakteru Żydów oraz ich roli w społeczeństwie polskim. Wszakże silne akcentowanie tego punktu nie sprzyja wyważonej ocenie problemu. Dystansując się od jednostronnych ocen Prusa, już to jako anty-, już to jako filosemity, Friedrich zauważyła:

Całkowite odrzucenie perspektywy Zagłady zapewne nie jest w ogóle możliwe, jednak nadmierne podporządkowanie tej perspektywie rozważań nad przeszłością zbyt często prowadzi do wniosków pochopnych, jeśli nie fałszywych (...). Rozumienie teraźniejszości nie może się bowiem (...) odbywać za cenę oskarżania przeszłości (Friedrich 2008, 11).

Jest rzeczą bezsporną, że pisarz krytycznie oceniał mentalność żydostwa tradycyjnego, które - jego zdaniem - izolowało się od Polaków i skupiało na spekulacjach finansowych, lichwie, faktorstwie, wzniecając tym sposobem niechęć i nienawiść u współobywateli polskich, przekształcające się często w nastawienie antysemickie. Rzecz interesująca: Prus długo bo aż do 1889 roku (zob. Friedrich 2008, 243 i nn.) - nie uważał Żydów za naród, sądził, iż nie posiadając klasy rolniczej ani własnego terytorium, stanowią oni jedynie kastę. Gorąco popierał pomysł zmiany polegającej na przeniesieniu się części miejskiej ludności żydowskiej na wieś i podjęciu przez nią pracy na roli. Separatyzm żydowski w znacznej mierze wynikał - według Prusa - z faktu, iż Żydzi skupili się w swoich gettach z powodu szykan i prześladowań ze strony chrześcijan. Solidarność Żydów była ich bronią przeciwko opresjom z zewnątrz. W mniemaniu pisarza stosunki polsko-żydowskie powinny się opierać na współpracy i wzajemnym poszanowaniu własnej niezależności, a także na poczuciu praw i obowiązków, wynikających z przynależności do jednego organizmu społecznego. Rozwój oświaty i wychowania, odrzucenie ksenofobii i wszelkich przejawów nienawiści religijnej oraz rasowej uznawał Prus za środki niezbędne do przezwyciężenia licznych chorób polskiego społeczeństwa.

W latach 70. XIX wieku Prus opowiadał się za programem asymilacji Żydów. Uważał, iż konieczne jest zniesienie nieprzekraczalnych barier między społeczeństwem polskim a ludnością żydowską. Stanowczo przeciwstawiał się strategii wykluczania Żydów, uznawanych przez polskie środowiska antysemickie za obcych lub nawet wrogich Polakom; domagał się jednak tego, by Żydzi zasymilowali się do polskiego organizmu społecznego. W 1876 roku zapisał w jednej ze swoich kronik piękne zdania, w których przekonywał, iż „Żydzi i chrześcijanie stanowią jedną całość, są elementami 
jednego organizmu, mimo różnice wiary, języka, zwyczajów, a nawet tradycji” (Głowacki 1876, 219). I konkludował: „Oni nie mogą się obejść bez nas, my bez nich" (Głowacki 1876, 219).

Z największym uznaniem odnosił się Prus do postaw tych wszystkich Żydów, którzy dzięki oświacie i emancypacji przekraczali bariery oddzielające obie zbiorowości. Oceniał ich wszakże z perspektywy polocentrycznej. Sądził, na przykład, że ceniony lekarz Henryk Nusbaum, Żyd zasymilowany, stał się Polakiem i zupełnie zbytecznie "obnosił się" ze swoim żydostwem w manifeście o inc. "Jestem Żydem”, zamieszczonym w 1886 roku na łamach pierwszego numeru "Głosu” ${ }^{5}$. Dlaczego było to - zdaniem pisarza - postępowanie niewłaściwe? Prus wyjaśniał:

p. Nusbaum nie jest Żydem, gdyż zamiast chodzić w brudnym chałacie i wiecznie rozpiętych spodniach ubiera się schludnie i po europejsku. Zamiast mówić żargonem mówi zupełnie poprawną polszczyzną. Zamiast czytać Talmud uczy się nauk przyrodniczych. Zamiast brać się do wątpliwego pośrednictwa, do pożyczania pieniędzy na lichwę, do paserstwa albo do utrzymywania domów publicznych i innych zajęć niemających związku z "miłością bliźniego” i z „cnotą obywatelską” wziął się do medycyny i literatury (Prus 1886, 1).

Dalszy ciąg cytowanej kroniki poświadczał fakt, iż Prus ulegał myśleniu stereotypowemu, definiując bowiem znaczenie terminu „żydostwo”, unikał wszelkich odniesień wyznaniowych i etnicznych, przypisywał mu zaś cechy skrajnie negatywne: „ciemnotę, pychę, separatyzm, próżniactwo i wyzysk” (Prus 1886,1$)^{6}$. Ten ostry osąd publicystyczny nie przeniknął bezpośrednio do Lalki, jakkolwiek zawarte w powieści negatywne opinie o Żydach odwoływały się do stereotypu geszefciarstwa i finansowego wyzysku, które miały charakteryzować semitów.

Prus, jak można sądzić, uważał, że izolacjonizm współczesnych Żydów oraz wszystkie ich negatywne cechy były konsekwencją wielowiekowych represji i prześladowań, jakim ich poddawano. W rezultacie ostali się najgorsi. Pogląd taki - popierany najpewniej przez samego pisarza - wygłosił Wokulski w odpowiedzi na uwagę Rzeckiego o możliwej kolejnej „awanturze" z Żydami:

Bywały już, trwały przez ośmnaście wieków i jaki rezultat?... W antyżydowskich prześladowaniach zginęły najszlachetniejsze jednostki, a zostały tylko takie, które mogły uchronić się od zagłady. I oto jakich mamy dziś Żydów: wytrwałych,

\footnotetext{
${ }^{5}$ Wydaje się, że Prus tendencyjnie uprościł motywację i sens wystąpienia Nusbauma, przekonując, iż ten ceniony lekarz nie miał powodów do stawiania się w roli ofiary, ponieważ sytuacja Żydów w Królestwie Polskim była mimo wszystko lepsza aniżeli np. Polaków w zaborze pruskim. Helena Datner potraktowała manifest Nusbauma jako przejaw „postawy motywowane[j] także względami natury moralnej”. Chodziło tu o to, że „za rzecz niegodną uważano odejście od społeczeństwa żydowskiego w chwili, w której żydostwo stawało się ciężarem szczególnym” (Datner 2007, 181).

${ }^{6}$ Odnotować tu trzeba, że tę wypowiedź Prusa z roku 1886 Alina Cała - autorka skądinąd wartościowej monografii o asymilacji Żydów - uznała za dowód tego, że pisarz właśnie wtedy „zaczął się skłaniać ku antysemityzmowi” (Cała 1989, 264). Sformułowana przez Całą ogólna ocena podejścia Prusa do kwestii żydowskiej wydaje się zbyt jednostronna, kładzie bowiem silny akcent na zawarte w nim treści negatywne, niewolne od komponentów antysemickich. Podobnie - a nawet jeszcze bardziej zdecydowanie - potraktowała opinię Całej o Prusie - Friedrich, dla której sądy badaczki odznaczały się ewidentnym uproszczeniem (zob. Friedrich 2008, 24-26, 28-29).
} 
cierpliwych, podstępnych, solidarnych, sprytnych i po mistrzowsku władających jedyną bronią, jaka im pozostała - pieniędzmi. Tępiąc wszystko, co lepsze, zrobiliśmy dobór sztuczny i wypielęgnowaliśmy najgorszych (Prus 1998, II 406-407).

Tą szokującą - z dzisiejszej perspektywy - retoryką posłużył się Wokulski w chwili emocjonalnego rozdrażnienia, jednak w dyskursach epoki Prusa stosowano ją niejednokrotnie. Bohater odwołał się do konstrukcji myślowej socjaldarwinizmu (i związanej z nią koncepcji doboru), wyjaśniającej mechanizm ostrych walk i konfliktów między jednostkami, klasami społecznymi, wyznaniami, narodami. Triumf „najgorszych” Żydów zyskał tu uzasadnienie (pseudo)naukowe.

W Lalce dominuje motyw narastającego konfliktu między Polakami a Żydami. Zarówno pierwsi, jak i drudzy dostrzegają to zjawisko, przy czym najjaskrawiej odzwierciedla się ono na płaszczyźnie ekonomicznej. Rację miała Friedrich, pisząc, iż Prus - pomimo kierowanych do rodaków apeli, by bliżej poznawali życie Żydów - nie przejawiał większej fascynacji kulturą żydowską, co odróżniało go, na przykład, od Elizy Orzeszkowej (zob. Friedrich 2008, 184). Ekonomiczne podłoże konfliktów powieściowych Lalki stanowiło najistotniejsze źródło zarówno postaw antysemickich, jak i separatyzmu żydowskiego. Po sprzedaży przez Wokulskiego sklepu Szlangbaumowi Rzecki z ubolewaniem zapytuje przyjaciela: „- Czy jednak pomyślałeś, że gdy twój sklep przejdzie w ich ręce, kilkudziesięciu Żydów zyska popłatną pracę, a kilkudziesięciu naszych ludzi straci ją?" (Prus 1998, II 407). Tymczasem u podstaw tej transakcji leży zamiar dostania się na salony; pozbycie się kompromitującej - w oczach Izabeli i większości polskiej arystokracji - etykiety kupca ma polepszyć notowania Wokulskiego i przełamać niechęć wybranki.

Polacy w Lalce ponoszą ekonomiczne klęski w konkurencji z Żydami, których praktyki oceniane są często jako „geszeft” (zob. Szweykowski 1927, 269-270). Rzecki, bystry acz niewolny od posługiwania się stereotypami obserwator, dostrzega panoszenie się nowego właściciela sklepu, Szlangbauma, oraz reakcje Polaków na takie zachowania Żydów. Wprawdzie w odczuciu Prusa były te reakcje dowodem umysłowej niedojrzałości i słabości, niemniej podsycały atmosferę wzajemnych niechęci i zaogniały konflikt. Rzecki notował w pamiętniku:

I kiedy tak Szlangbaum zadziera nosa, w mieście na Żydów krzyk. Ile razy wstąpię na piwo, zawsze ktoś napada mnie i wymyśla, że Stach sprzedał sklep Żydom. Radca narzeka, że Żydzi zabierają mu trzecią część emerytury; Szprot utyskuje, że Żydzi popsuli mu interesa; Lisiecki płacze, że mu Szlangbaum wymówił miejsce od świętego Jana (Prus 1998, II 539-540).

Stary subiekt $\mathrm{z}$ niepokojem zauważa zmianę w postawie Henryka Szlagbauma, rzekomo potwierdzającą istnienie skaz w psychice żydowskiej.

Nie mogę (...) ukryć przed sobą - pisał rozżalony Rzecki - że Szlangbaum mocno zmienił się w ciągu roku. 
Dawniej był potulny, dziś arogant i pogardliwy; dawniej milczał, kiedy go krzywdzono, dziś sam rozbija się bez powodu. Dawniej mianował się Polakiem, dziś chełpi się ze swego żydostwa. Dawniej nawet wierzył w szlachetność i bezinteresowność, a teraz mówi tylko o swoich pieniądzach i stosunkach. Może być źle!...

Za to wobec gości jest uniżony, a hrabiom, a nawet baronom właziłby pod podeszwy. Ale wobec swoich podwładnych istny hipopotam: ciągle parska i depcze ludzi po nogach. To nawet nie jest pięknie... Swoją drogą radca, Szprot, Klejn i Lisiecki nie mają racji grozić jakimiś awanturami (Prus 1998, II 543-544).

Ostatnie zdanie ma doniosłe znaczenie. To sprzeciw wobec gróźb w stosunku do Żydów. Już niebawem miały się one spełnić w pogromie warszawskim z grudnia 1881 roku. Prus tracił nadzieję na pomyślne rezultaty procesów asymilacyjnych; coraz trudniej było mu formułować tezy nawiązujące do jego wystąpień z lat 70., gdy Polaków i Żydów włączał w jeden organizm społeczny. Owszem, nigdy nie zarzucił swoich pomysłów organicystycznych, ale jego nadzieje na postępy asymilacji Żydów nie spełniały się.

Choć stosunki polsko-żydowskie w Lalce mrocznieją z biegiem akcji, to jednak cechą charakterystyczną obrazu świata w tej powieści jest historia przyjaźni Wokulskiego z Szumanem oraz z młodszym Szlangbaumem. Sandler zauważył, iż te przyjacielskie, wręcz zażyłe relacje Polaka i Żydów były czymś zgoła wyjątkowym na tle polskiej tradycji literackiej w wieku XIX (zob. Sandler 2016, 171)7 . Co więcej, historie tych relacji oraz ich geneza zostały przez Prusa przedstawione w sposób znamienny i głęboko przemyślany, co miało swoją szczególną wymowę w czasie nasilających się nastrojów antysemickich, a także zawierało przesłanie patriotyczne. „Blisko dwadzieścia lat wcześniej - pisał o Wokulskim, Szumanie i Henryku Szlangbaumie Sandler - poznali się i związali. Wokulski i jego żydowscy przyjaciele brali udział w działaniach konspiracyjnych i powstaniu zbrojnym przeciwko Rosji, co razem opłacili karnym zesłaniem na Syberię" (Sandler 2016, 172).

Wątek zesłańczy musiał Prus zaszyfrować w języku ezopowym, często wykorzystywanym przez pisarzy pozytywistycznych do opisu zdarzeń i doświadczeń, których opis bezpośredni był zakazany przez rosyjską cenzurę. Ten ważny element biografii Wokulskiego, Szumana i Szlangbauma poświadczał wspólnotę losu Polaków i Żydów w najdramatyczniejszym momencie historii Polski w drugiej połowie XIX wieku. Czas przedpowstaniowych demonstracji i powstania styczniowego obfitował w przykłady polsko-żydowskiego braterstwa; w Lalce stanowi on odległą reminiscencję, której wymowa ideowa nie przystaje do teraźniejszości, ale funkcjonuje jako utajona wartość.

${ }^{7}$ Pięknym objawem nieprzemijającej przyjaźni jest stosunek Wokulskiego do Henryka Szlangbauma, który poszukiwał pracy; przyjaciel zatrudnił go w swoim sklepie. Młodszy Szlangbaum z wolna jednak odsuwa się od Wokulskiego. Fakt ten tłumaczy Sandler „postawą i aspiracjami żydowskiego przyjaciela, który, podobnie jak jego ojciec, jest bardzo chciwy i czyni wielkie starania, by się wzbogacić, co ma zapewnić mu pewien wyższy status bezpieczeństwa, poszanowania i akceptacji ze strony Polaków, także przedstawicieli arystokracji, o co zabiega" (Sandler 2016, 172). Z kolei sam Wokulski, opuściwszy jadłodajnię Hopfera, zdobył środki utrzymania dzięki pomocy Szumana, który wynalazł mu korepetycje w domach żydowskich. 
Najbliższym przyjacielem Wokulskiego jest lekarz Michał Szuman, jedna $\mathrm{z}$ najznakomitszych kreacji osobowych powieści. Historycy literatury zgodnie uznali tego bohatera za postać świetnie skonstruowaną, wielowymiarową, niejednoznaczną ${ }^{8}$. Sandler podkreślił wzrost znaczenia tej postaci w procesie historycznoliterackiej recepcji Lalki; nastąpił on - jak sądzi badacz - w wyniku wyostrzenia „świadomości tego, jaką formę «rozwiązanie» kwestii żydowskiej przybrało w pierwszej połowie XX wieku" (Sandler 2016, 173).

Błyskotliwie inteligentny, potrafi Szuman bezceremonialnie demaskować ukryte pobudki ludzkich działań, do swoich współbraci Żydów ma stosunek ambiwalentny. Jego powieściowa biografia obrazuje klęskę niegdysiejszego asymilatora, który powrócił do diaspory. Kochał Polkę, chrześcijankę, która, zaszczuta przez bliskich, umarła, on sam próbował popełnić samobójstwo. Odratowany przez kolegę lekarza, stracił praktykę, stał się (auto)ironicznym mizantropem. Jego uwagi dotyczące stosunków polsko-żydowskich oraz sytuacji samych Żydów stanowią bardzo ważny komponent tej problematyki w powieści. Szuman różnicuje zrazu swoje środowisko na chederowców i postępowców (asymilatorów), przekonując Wokulskiego, iż lepiej by było, gdyby rząd dusz w cywilizacji przejęli ci drudzy. Sugerując przyjacielowi oddanie interesu w ręce Żydów postępowych, Szuman stwierdza:

Nas z nimi łączy rasa i wspólne położenie, ale dzielą poglądy. My mamy naukę - oni Talmud, my rozum - oni spryt; my jesteśmy trochę kosmopolici, oni partykularyści, którzy nie widzą dalej poza swoją synagogę i gminę. Gdy chodzi o wspólnych nieprzyjaciół, są wybornymi sprzymierzeńcami, ale gdy o postęp judaizmu... wówczas są dla nas nieznośnym ciężarem. Dlatego w interesie cywilizacji leży, ażeby kierunek spraw był w naszych rękach. Tamci mogą tylko zaplugawić świat chałatami i cebulą, ale nie posunąć go naprzód... (Prus 1998, II 574-575).

Ta przyszłościowa wizja nie miała, rzecz jasna, szans na spełnienie w Lalce. Świadom tego był chyba i Szuman, który - jak napisał Sandler - „potrafi na przykład wyrazić się euforycznie o dyspozycjach i talentach «rasy żydowskiej» i okazać zarazem pełną pogardę dla niej" (Sandler 2016, 173). Pod koniec akcji doktor zdaje się jednać z Żydami tradycjonalistami, imponuje mu ich konsekwencja w działaniu, talent do interesów i odporność na ataki z zewnątrz. Przekonuje Wokulskiego, że spodziewany wzrost agresji antyżydowskiej tylko skonsoliduje diasporę:

Wiem, co mówi się o Żydach w warsztatach, szynkach, sklepach, nawet gazetach... I jestem pewny, że lada rok wybuchnie nowe prześladowanie, z którego moi bracia w Izraelu wyjdą jeszcze mędrsi, jeszcze silniejsi i jeszcze solidarniejsi... A jak oni wam kiedy zapłacą!... Szelmy spod ciemnej gwiazdy, ale - muszę uznać ich geniusz i nie mogę wyprzeć się sympatii... Czuję, że dla mnie brudny Żydziak jest milszym od umytego panicza; a kiedy po dwudziestu latach pierwszy raz zajrzałem

${ }^{8}$ Postać Żyda lekarza z Lalki to najwybitniejsza kreacja bohatera tego typu w literaturze polskiej. Zob. Datner 2007, 174. 
do synagogi i usłyszałem śpiewy, na honor, łzy mi w oczach stanęły... Co tu gadać... Pięknym jest Izrael triumfujący i miło pomyśleć, że w tym triumfie uciśnionych jest cząstka mojej pracy!... (Prus 1998, II 571-572)

Historia miała się potoczyć inaczej. Szuman w swojej apologii potęgi pieniądza, którą najlepiej wykorzystują Żydzi, nie jest jednak bezrefleksyjnym wyznawcą poziomego materializmu. Jako fanatyk nauki nie mógł przecież całkowicie zakwestionować idealizmu tych wszystkich, którzy poświęcają się celom wyższym. Dlatego nie potrafił znaleźć odpowiedzi na znamienne pytanie Rzeckiego o to: „co byłoby więcej warte dla świata: czy spryt Szlangbaumów, czy marzycielstwo Wokulskich i Ochockich?” (Prus 1998, II 456-457) ${ }^{10}$.

Idealiści ponoszą w Lalce praktyczne klęski; nie oznaczają one przecież ideowych ani moralnych porażek. Jest wręcz przeciwnie, o czym już wielokrotnie pisano. Stosunki polsko-żydowskie w powieści ewoluują w stronę coraz ostrzejszego konfliktu, animozji, nieufności czy wręcz nienawiści. Prus niczym czuły sejsmograf uchwycił tę atmosferę w życiu publicznym Warszawy schyłku lat 70. XIX stulecia. Odczuwał ją i odnotowywał także Rzecki, bohater wykreowany przez pisarza na (pozornie) naiwnego idealistę, spadkobierca idei Oświecenia i demokratycznego romantyzmu, człowiek dostrzegający przewiny współczesnych mu Żydów, ale w imię wyznawanych zasad przeciwny nienawiściom i przemocy. Znamiennie wybrzmiewa protest starego subiekta przeciwko pogróżkom, jakie wygłasza wobec starozakonnych Klejn, posługujący się ostrą, popularną w środowiskach antysemitów opozycją: my (Polacy) - oni (Żydzi). Wykluczenie Żydów ze wspólnoty ludzi równych oburza Rzeckiego:

(...) co znaczą owe: $\mathrm{m} \mathrm{y}-\mathrm{n}$ a s?...

I to ma być wiek, który nastąpił po XVIII, po tym XVIII wieku, co napisał na swoich sztandarach: wolność, równość, braterstwo?... Za cóż ja się, u diabła, biłem z Austriakami?... Za co ginęli moi kamraci?... (Prus 1998, II 541-542).

Powieściowy wyznawca ideałów wolnościowych i egalitarnych nie doczekał ich spełnienia. Historia Europy w ciągu półwiecza po wydaniu Lalki potoczyła się wszak zupełnie odmiennie. Wzrost tendencji nacjonalistycznych i antysemityzmu miał doprowadzić do wielu katastrof. Prus w Lalce ukazał przejawy negatywnych tendencji psychospołecznych. Powieściowi Polacy i Żydzi coraz bardziej separowali się od siebie, a nasilanie się nastrojów antysemickich nakłaniało tych drugich do zamykania się w swojej

\footnotetext{
${ }^{9}$ Zdaniem Burdzieja, Prus, tworząc tę separatystyczną wypowiedź Szumana, „oskarża[ł] tę część współczesnych Żydów «oświeconych», która zaniechała oddziaływania na swych braci z religijnego i cywilizacyjnego getta oraz mediacji między Polakami a Żydami” (Burdziej 1998, 189).

${ }^{10}$ Szuman znajduje się w stanie zawieszenia, nie może zespolić się z żadną grupą; w mniemaniu Sandlera: „Już nie ma dla niego miejsca w społeczności żydowskiej, którą dawno opuścił, a wie, że nie będzie przez społeczeństwo polskie nigdy widziany inaczej niż jako Żyd" (Sandler 2016, 176). Trzeba wszak zauważyć, iż żydowski lekarz niezmiennie podkreśla swoje przywiązanie do przyjaciela, gdy ten, osamotniony, czuje wyobcowanie w sferze polskiej arystokracji. Mówi do Wokulskiego: „- Pomyśl zresztą - ciągnął Szuman - kto dziś jest przy tobie?... Ja, Żyd, tak pogardzony i tak skrzywdzony jak ty... I przez tych samych ludzi... przez wielkich panów... (Prus 1998 II, 572). Uderza w tej wypowiedzi poczucie wspólnoty dwóch odtrąconych.
} 
diasporze. Choć Lalka - powtórzmy - nie była wolna od stereotypowych ujęć Żydów, ich mentalności i roli w społeczeństwie polskim, to jednak Prus nigdy nie wyrzekł się swoich głęboko humanitarnych i równościowych poglądów. Owszem, zdarzało mu się w krytyce Żydów popadać w retorykę z dzisiejszego punktu widzenia niebezpieczną, niemniej zawsze stanowczo przeciwstawiał się wszelkim aktom przemocy i polityce nienawiści wobec Żydów. U schyłku życia - w 1910 roku - przywołał wspomnienie chlubnej karty w stosunkach polsko-żydowskich, zaistniałej w czasach przedpowstaniowych demonstracji poprzedzających insurekcję styczniową. W odczuciu Prusa wytworzył się wówczas wyjątkowy solidaryzm społeczny i poczucie wspólnoty, łączące Polaków z Żydami. Jak pisał:

Serdeczność szczególniej uwydatniała się w stosunkach chrześcijan z Żydami; dość przypomnieć o wspólnych demonstracjach, wzajemnym odwiedzaniu kościołów i bożnic albo o ofiarach składanych na cele żydowskie przez chrześcijan, a na chrześcijańskie przez wyznawców Starego Zakonu. Każdy pamiętający owe czasy może sobie powiedzieć: „Miałem wiosnę w moim życiu!” (Prus 1910, 1004).

Te piękne chwile solidarności i wspólnoty Polaków i Żydów jawiły się Prusowi jako wzór pojednania i współistnienia ludzi, należących do jednego organizmu społecznego. Antytezę tego ideału stanowił obraz stosunków polsko-żydowskich w Lalce. Obraz bardzo pesymistyczny, naznaczony, jak już tu wspominano, atmosferą narastającego konfliktu. Ekonomiczny triumf powieściowych Żydów traktował Prus jako jedną z głównych przyczyn warszawskiego pogromu z grudnia 1881 roku. Pisarz długo żywił nadzieję na rozwiązanie problemów polsko-żydowskich w duchu wspólnotowym. Żydów pragnął włączyć w obręb polskiego społeczeństwa w taki sposób, by stanowili jego ważną część, współistniejącą z Polakami na zasadzie „wspierania się i wymiany usług". To inkluzywne spojrzenie na wszystkie mniejszości wyróżniało Prusa.

Współczesna interpretacja tematyki żydowskiej Lalki nie jest przedsięwzięciem prostym ani niekontrowersyjnym. Wymaga ona historycznokulturowej kontekstualizacji, dzięki której można niektóre wątpliwe sądy pisarza wyjaśnić w ich macierzystym otoczu. Świadom tych wszystkich uwarunkowań Prusowskiego stosunku do kwestii żydowskiej, Sandler sformułował przekonujący sąd ogólny:

Niekiedy polemizowano z jego ujęciami, czasem zgodnymi ze stereotypowymi, negatywnymi opiniami, powszechnymi w kulturze polskiej i wielowiekowej tradycji chrześcijańskiej, gdzie już sama nazwa „Żyd” miała ujemne konotacje. Ale w zasadzie widziano, że spod pióra Prusa wychodziły jednak przede wszystkim apele potępiające wszelkie formy prześladowania, dyskryminacji i ograniczeń, tak liczne w wielowiekowej historii Żydów europejskich (Sandler 2016, 167).

Mrok zasnuwający świat przedstawiony Lalki wywołuje w czytelniku odczucie wszechogarniającego kryzysu i pesymizmu, przyćmiewa też niegdysiejsze, braterskie lub przynajmniej przyjacielskie, relacje Polaków 
i Żydów. Prus ukazał w powieści proces ich stopniowego pogarszania się. I jakkolwiek wyjaśniając przyczyny tego stanu rzeczy, sprowadzał je prawie wyłącznie (i nazbyt wąsko) do płaszczyzny ekonomicznej, to jednak - jeśli rozpatrywać rzecz całą w kontekście współczesnej pisarzowi epoki

- stanowczo odrzucał przemoc i nienawiść w stosunku do Żydów. Trzeba o tym pamiętać, czytając dzisiaj Lalkę i poświęconą sprawom żydowskim publicystykę Prusa. W jego stosunku do Żydów odnajdzie się bowiem i treści moralnie dyskwalifikujące (z punktu widzenia świadomości po Zagładzie), i - przeważający nad nimi - szlachetny humanitaryzm, jaśniejący na tle epoki Lalki.

\section{Bibliografia:}

Bachórz Józef, 1998, Wstęp do: Prus B., Lalka, Bachórz J. (oprac.), BN I 262, Wrocław.

Burdziej Bogdan, 1998, „Lalka” Prusa o genezie pogromu warszawskiego (1881). Rekonesans problemu, w: Jubileuszowe „żniwo u Prusa”, Przybyła Z. (red.), Częstochowa.

Cała Alina, 1998, Asymilacja Żydów w Królestwie Polskim. Postawy. Konflikty. Stereotypy, Warszawa.

Datner Helena, 2007, Ta i tamta strona. Żydowska inteligencja Warszawy drugiej połowy XIX wieku, Warszawa.

Friedrich Agnieszka, 2008, Bolesław Prus wobec kwestii żydowskiej, Gdańsk.

Głowacki Aleksander (Bolesław Prus), 1876, Kronika miesięczna, „Ateneum”, t. 4, z. 11.

Kwestia żydowska w XIX wieku. Spory o tożsamość Polaków, 2004, Borkowska G., Rudkowska M. (red.), Warszawa.

Markiewicz Henryk, 1994, Asymilacja Żydów jako temat literatury polskiej, w: Literatura i historia, Kraków.

Molisak Alina, 2017, Wstęp do hebrajskiego wydania „Lalki” Bolesława Prusa, „Przegląd Humanistyczny”, nr 3.

Prus Bolesław, 1886, Kronika tygodniowa, „Kurier Warszawski”, nr 280.

Prus Bolesław, 1910, Miasto zahipnotyzowane, „Tygodnik Ilustrowany”, nr 50.

Prus Bolesław, 1998, Lalka, Bachórz J. (oprac.), BN I 262, Wrocław.

Sandler Samuel, 2016, Żydzi i sprawy żydowskie w "Lalce” Bolesława Prusa, „Wiek XIX. Rocznik Towarzystwa Literackiego im. Adama Mickiewicza”.

Sandler Samuel, 2017, Wstęp, „Przegląd Humanistyczny”, nr 3.

Szweykowski Zygmunt, 1927, „Lalka” Bolesława Prusa, Warszawa. 


\section{O Autorze:}

Tomasz Sobieraj - prof. dr hab. w Instytucie Filologii Polskiej UAM w Poznaniu, kierownik Zakładu Literatury Pozytywizmu i Młodej Polski. Jego zainteresowania naukowe to kulturowa historia literatury okresu pozytywizmu i Młodej Polski (w tym związki literatury z naukami przyrodniczymi), krytyka literacka i teatralna. Najnowsze publikacje książkowe: Między konwencja a innowacja. Szkice o polskim dramacie i teatrze drugiej połowy XIX i początku XX wieku (2018), Artysta, sztuka i społeczeństwo. Spory i polemiki wokół „Confiteor” Stanisława Przybyszewskiego (2019). 
